\title{
Oak killer found in rhododendrons
}

cores of beetles scurry around bleeding

trunks. Tall, once-verdant tanoaks are crowned with dry brown leaves. "Sudden oak death" (SOD) has felled tens of thousands of oaks, creating ominous scenes in coastal landscapes.

UC scientists, who first identified the pathogen as a Phytophthora species, have now found the same disease agent in Santa Cruz County rhododendrons. This suggests the disease agent could spread over long distances on ornamental plants, and that it may be able to infect other plants as well.

The counties hardest hit by SOD have been Marin, Sonoma and Santa Cruz, but it is also present in Monterey, Napa, Santa Clara and San Mateo. UC Berkeley geographer Nina Maggi Kelly has been monitoring and mapping the infestations (see p. 9). The exact number of trees that have succumbed to SOD is unknown, but using field plots, aerial photography and satellite imagery, Kelly hopes to understand the overall impacts of the disease on oak forests and the surrounding communities.

"Never before have we experienced such a rapid death of oaks," says Marin County horticulture advisor Pavel Svihra. "When symptoms start to manifest, it will last no more than 6 to 8 weeks, then the tree is gone."

\section{Discovery in rhododendrons}

In summer 2000, UC forest pathologists David Rizzo and Matteo Garbelotto determined that the disease is caused by a yet unnamed species of Phytophthora. Rizzo says the pathogen is technically a "killer brown algae," but is commonly referred to as a fungus.

A tip from a European colleague led the scientists to investigate rhododendron plants as a possible carrier of the fungus. The collaboration revealed that the same pathogen that is killing oaks in California may also attack rhododendrons in Germany and the Netherlands; however, the pathogen has not been observed on oaks in Europe. In December, Rizzo and Steve Tjosvold, a Santa Cruz County farm advisor, detected the fungus in a rhododendron from a Santa Cruz nursery.

It is unusual to find a new pathogen in two geographical areas that are so far apart, the researchers said. "We don't know whether the disease was transmitted from California to Eu- rope, or vice versa, or originated from a third, unknown location," Rizzo says.

\section{Oregon orders quarantine}

The Phytophthora's ability to infest rhododendrons will complicate measures to halt spread of SOD and could provoke international quarantine regulations for the nursery industry.

Growers have been able to control the Phytophthora on rhododendrons, but chemicals often do not eradicate the fungus in the plant. "The worry is that a rhododendron will be sold that has a disease," Rizzo says. "There's no great trade in oaks, but there is a great trade in rhododendrons in this country and internationally."

A close relative, Phytophthora lateralis, has killed thousands of Port Orford cedar in the Pacific Northwest. To protect Oregon's agricultural industries and natural resources from SOD, the Oregon Department of Agriculture ordered an emergency quarantine effective until April 4, 2001. The quarantine restricts tanoak (Lithocarpus densiflorus), black oak (Quercus kelloggii), coast live oak ( $Q$. agrifolia) and any other plant species found to be susceptible to this disease, and associated plant material and soil. Rhododendrons have now been added to the quarantine list.

Oregon's quarantine prohibits wood products originating from SOD-infested counties unless the products have been kiln-dried or heattreated to $160^{\circ} \mathrm{F}$ for 75 minutes. Rhododendrons must be certified disease-free. Violators of this quarantine may face a fine of up to $\$ 5,000$ and civil penalties of up to $\$ 10,000$.

\section{Monitoring SOD spread}

The newly formed California Oak Mortality Task Force has been monitoring the epidemic.
Coast live oak, shown, as well as tanoak and black oak are succumbing by the thousands to a syndrome caused by a newly discovered species of Phytophthora.

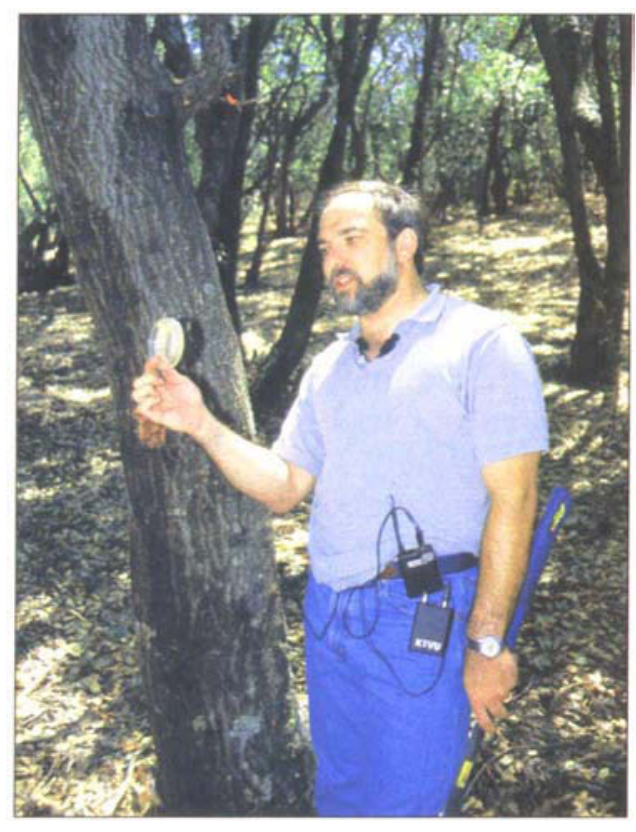

The Phytophthora that kills oaks has also been found in rhododendrons. This discovery poses new challenges for controlling the fungus, says UC Davis plant pathologist David Rizzo. 


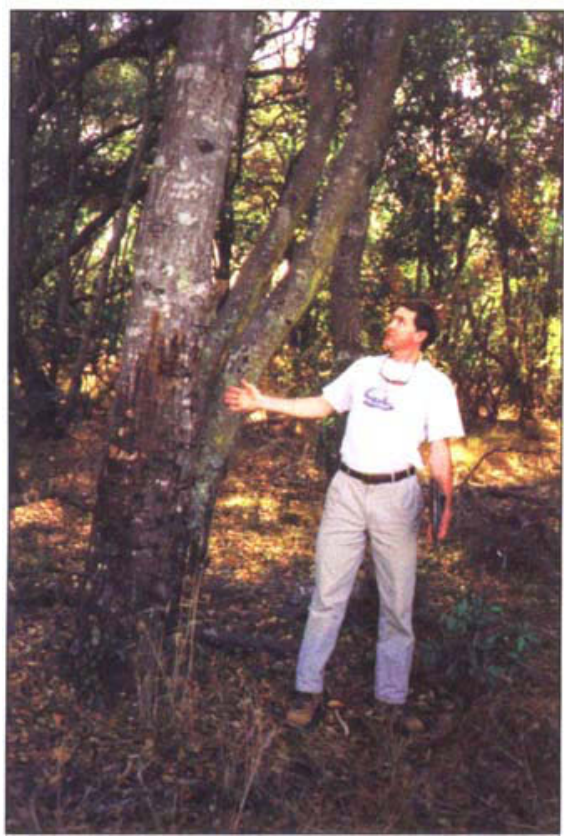

UC Berkeley postgraduate researcher Brice McPherson points to a bleeding canker, a symptom of sudden oak death syndrome.
To document oak mortality and oak tree removal from areas possibly infected with SOD, researchers are using an Internet tool: the OakMapper Web site. OakMapper uses WebGIS (geographic information systems) technology, which enables users to browse the map and submit the location and condition of infected trees.

"People can contribute information by going to the Web site and filling in the form," says geographer Kelly, who specializes in remote sensing. "This data will be mapped to the overall monitoring database. The goals of the project are to allow public involvement in the process, to educate the public about $\mathrm{SOD}$, to assist in the screening process so that we can forward these new reports to the county staff involved in sudden oak death, and to alert us to new hot spots."

Scientists are trying to determine how the fungus is spread. Although the western oak bark beetle (Pseudopityophthorus pubipennis) and two species of ambrosia beetle (Monarthrum scutellare and $M$. dentiger) appear on the dead trees, they are not believed to be spreading the fungus. The pathogen is only found on aboveground plant parts such as stems, branches and leaves. This suggests the pathogen may be moved through the air somehow. Rainsplash or wind-driven rain seems the most likely pathway. Rizzo's lab has isolated the fungus from 60 feet up in a tanoak that did not have visible cankers lower on the trunk. The European Phytophthora is also known to produce lesions on branches and leaves of rhododendrons.

SOD might also be moved in plant material. Jenny Davidson, a postdoctoral researcher, recovered Phytophthora from a tree that had been cut down. Rizzo warns people not to move firewood from infected counties because they might spread the disease. "I fear that people will take infected wood to Yosemite Valley. Those are black oaks in Yosemite," Rizzo says.

The fact that rhododendrons can harbor the pathogen casts suspicion on the plant's relatives. "We're already tromping around the woods to find if this fungus goes to other plants," Rizzo says.

\section{Hope for SOD resistance}

Tanoak appears to be more susceptible than coast live oak to this new Phytophthora species. But variation in tree response to artificial infections in the field indicates there may be some natural resistance present in coast live oak populations. "We have evidence there may be some resistance," Rizzo says. "When we inoculate trees, there's quite a range in susceptibility."

Rizzo hopes to find some resistant individuals of oak. "As people restore riparian areas, it would be nice to know if we can plant resistant material."

Of course, testing coast live oak could take years, Rizzo points out. "It's not like a tomato plant."

In the meantime, Garbelotto is testing fungicides that control Phytophthora in rhododendrons and other chemicals to see if they are effective in oaks.

\section{Increasing awareness of oak deaths}

Horticulture advisor Svihra and other Cooperative Extension personnel have worked with the media and the public to increase awareness of the oak mortality.

"We encouraged concerned citizens to contact newspapers and county supervisors," says Svihra. "When tanoaks and coast live oaks were dying as far south as Big Sur, it was clear that the problem was no longer local.

"Eventually, Marin County supervisors realized that the economical, ecological and fire hazards of dead trees had been greatly underestimated. In January 2000 they appropriated $\$ 5,000$ for UC Cooperative Extension in Marin County to appoint an SOD task force, staffed by professionals."

Svihra published three issues of the newsletter UC Pest Alert focusing on SOD. He distributed 15,000 copies. During 2000, more than 30 local and regional workshops were held for arborists, horticulturists, landscape contractors and homeowners. About 6,000 copies of Homeowner's Guide, UC recommendations on insect control and plant health care, were distributed.

UC scientists have teamed up with colleagues in the California Department of Forestry, the U.S. Forest Service, California Department of Agriculture, California State University and others and are working on many aspects of sudden oak death syndrome in an attempt to arrest the pathogen.

- Pam Kan-Rice 